\title{
О ПОДХОДАХ К АНАЛИЗУ РИСКОВ СИСТЕМЫ ВЫСШЕГО ПРОФЕССИОНАЛЬНОГО ОБРАЗОВАНИЯ РОССИЙСКОЙ ФЕДЕРАЦИИ В ПРОЕКЦИИ ЕЕ ЭКОНОМИЧЕСКОЙ БЕЗОПАСНОСТИ
}

\author{
(c) 2019 Николаева Елена Анатольевна \\ кандидат социологических наук, доцент кафедры иностранных языков № 3 \\ Российский экономический университет им. Г.В. Плеханова, Россия, Москва \\ E-mail: yoltash82@mail.ru \\ (c) 2019 Соколова Екатерина Иосифовна \\ кандидат филологических наук, доцент кафедры иностранных языков № 3 \\ Российский экономический университет им. Г.В. Плеханова, Россия, Москва \\ E-mail:kafmkk@mail.ru \\ (C) 2019 Тарарина Лариса Игоревна \\ кандидат педагогических наук, доцент кафедры лингвистики и перевода \\ Российский государственный социальный университет, Россия, Москва \\ E-mail: it31@mail.ru \\ (c) 2019 Марциновская Виктория Александровна \\ старший преподаватель кафедры иностранных языков № 3 \\ Российский экономический университет им. Г.В. Плеханова, Россия, Москва \\ Email: vitam1981@mail.ru
}

\begin{abstract}
В статье авторов рассматривается вопрос анализа рисков системы высшего профессионального образования в проекции ее экономической безопасности. Объектом исследования выступила система профессионального образования Российской Федерации, а предметом - подходы к анализу ее рисков в проекции экономической безопасности. Теоретическое и методологическое значения исследования заключены в расширении классификационных представлений вопроса анализа рисков системы высшего профессионального образования. Практическое значение исследования определяется выявлением распределением относительной актуальности акцентов в рамках различных подходов в аспекте их применимости в современных реалиях.
\end{abstract}

Ключевые слова: Подходы, анализ, риски, высшее профессиональное образование, Российская Федерация, проекция, экономическая безопасность.

Экономическая безопасность [1, с.63] страны всегда являлась определяющим фактором ее успешного развития, как на мировой арене, так и в аспекте внутреннего положения дел.

На современном этапе развития мирового сообщества экономическая безопасность конкретной страны определяется интегральным состоянием множества факторов различного порядка в рамках элементов от оборонно-промышленного комплекса и добычи полезных ископаемых до системы высшего профессионального образования [3, с.77] (таблица 1).

Из таблицы 1 мы можем увидеть, что на примере Российской Федерации риски экономической безопасности являются низкими лишь по одной из представленных сфер. Именно поэтом актуальность рассматриваемого вопроса по практически всем представленным элементам, на наш взгляд, требует тщательного и сбалансированного изучения в многоаспектном формате.

В целях настоящего исследования в проекции целевого анализа темы для Российской Федерации рассмотрим более подробно систему высшего профессионального образования $[1,5]$ и имеющих там место рисков [2, с.17] (таблица 2), влияющих на экономическую безопасность $[4$, с.89] страны.

Из таблицы 2 можно увидеть следующее:

- наиболее значимо на экономическую безопасность Российской Федерации влияют социальные риски $[5,10]$, уровень которых оценивается в 75 баллов из 100 возможных;

- менее активно на проблему оказывают влияют риски технологического и экономиче- 
Таблица 1. Некоторые элементы, определяющие состояние экономической безопасности страны на мировой арене на 01.01.2019 года

\begin{tabular}{|c|c|c|}
\hline $\begin{array}{c}\text { Наименование } \\
\text { элемента }\end{array}$ & $\begin{array}{c}\text { Характеристика } \\
\text { элемента }\end{array}$ & Состояние рисков по элементу \\
\hline $\begin{array}{l}\text { Оборонно-промышленный } \\
\text { комплекс }\end{array}$ & $\begin{array}{l}\text { Характеризует состояние экономиче- } \\
\text { ской безопасности страны в аспекте } \\
\text { оборонно-промышленного комплекса }\end{array}$ & $\begin{array}{l}\text { Для Российской Федерации риски по } \\
\text { данному элементу в аспекте эконо- } \\
\text { мической безопасности являются } \\
\text { низкими }\end{array}$ \\
\hline Торговля & $\begin{array}{l}\text { Характеризует состояние экономиче- } \\
\text { ской безопасности страны в аспекте } \\
\text { торговли }\end{array}$ & $\begin{array}{l}\text { Для Российской Федерации риски по } \\
\text { данному элементу в аспекте эконо- } \\
\text { мической безопасности являются } \\
\text { высокими }\end{array}$ \\
\hline $\begin{array}{l}\text { Добыча полезных } \\
\text { ископаемых }\end{array}$ & $\begin{array}{l}\text { Характеризует состояние экономиче- } \\
\text { ской безопасности страны в аспекте } \\
\text { добычи полезных ископаемых }\end{array}$ & $\begin{array}{l}\text { Для Российской Федерации риски по } \\
\text { данному элементу в аспекте эконо- } \\
\text { мической безопасности являются } \\
\text { средними }\end{array}$ \\
\hline Строительство & $\begin{array}{l}\text { Характеризует состояние экономиче- } \\
\text { ской безопасности страны в аспекте } \\
\text { строительства }\end{array}$ & $\begin{array}{l}\text { Для Российской Федерации риски по } \\
\text { данному элементу в аспекте эконо- } \\
\text { мической безопасности являются } \\
\text { высокими } \\
\end{array}$ \\
\hline $\begin{array}{l}\text { Система высшего професси- } \\
\text { онального образования }\end{array}$ & $\begin{array}{l}\text { Характеризует состояние экономиче- } \\
\text { ской безопасности страны в аспекте } \\
\text { системы высшего профессионального } \\
\text { образования }\end{array}$ & $\begin{array}{l}\text { Для Российской Федерации риски по } \\
\text { данному элементу в аспекте эконо- } \\
\text { мической безопасности являются } \\
\text { высокими }\end{array}$ \\
\hline Прочие элементы & $\begin{array}{l}\text { Характеризует состояние экономиче- } \\
\text { ской безопасности страны в аспекте } \\
\text { прочих элементов }\end{array}$ & - \\
\hline
\end{tabular}

Примечание: в столбце три таблицы 1 приведен усредненный относительный уровень рисков экономической безопасности в качественном исполнении градации измерения (низкий, высокий, средний) для пяти элементов Российской Федерации, измеренный в 2019 году специалистами компании «Эксперт РА» [10].

\section{Таблица 2. Основные виды рисков, присущие системе высшего профессионального образования в} Российской Федерации

\begin{tabular}{|c|c|c|}
\hline Вид риска & $\begin{array}{c}\text { Характеристика } \\
\text { Вида риска }\end{array}$ & Дополнительная информация \\
\hline Политические & $\begin{array}{l}\text { Данный вид риска характеризует уязви- } \\
\text { мость системы профессионального образо- } \\
\text { вания в политических аспектах }\end{array}$ & $\begin{array}{l}\text { Оценка данного вида риска } \\
\text { для Российской Федерации на } \\
01.01 .2019 \text { года } 15 \text { из } 100 \text { баллов * }\end{array}$ \\
\hline Экономические & $\begin{array}{l}\text { Данный вид риска характеризует уязви- } \\
\text { мость системы профессионального образо- } \\
\text { вания в экономических аспектах }\end{array}$ & $\begin{array}{l}\text { Оценка данного вида риска } \\
\text { для Российской Федерации на } \\
01.01 .2019 \text { года } 55 \text { из } 100 \text { баллов }\end{array}$ \\
\hline Информационные & $\begin{array}{l}\text { Данный вид риска характеризует уязви- } \\
\text { мость системы профессионального образо- } \\
\text { вания в информационных аспектах }\end{array}$ & $\begin{array}{l}\text { Оценка данного вида риска } \\
\text { для Российской Федерации на } \\
01.01 .2019 \text { года } 45 \text { из } 100 \text { баллов }\end{array}$ \\
\hline Юридические & $\begin{array}{l}\text { Данный вид риска характеризует уязви- } \\
\text { мость системы профессионального образо- } \\
\text { вания в юридических аспектах }\end{array}$ & $\begin{array}{l}\text { Оценка данного вида риска } \\
\text { для Российской Федерации на } \\
01.01 .2019 \text { года } 35 \text { из } 100 \text { баллов }\end{array}$ \\
\hline Технологические & $\begin{array}{l}\text { Данный вид риска характеризует уязви- } \\
\text { мость системы профессионального образо- } \\
\text { вания в технологических аспектах }\end{array}$ & $\begin{array}{l}\text { Оценка данного вида риска } \\
\text { для Российской Федерации на } \\
\text { 01.01.2019 года } 65 \text { из } 100 \text { баллов }\end{array}$ \\
\hline Социальные & $\begin{array}{l}\text { Данный вид риска характеризует уязви- } \\
\text { мость системы профессионального образо- } \\
\text { вания в социальных аспектах }\end{array}$ & $\begin{array}{l}\text { Оценка данного вида риска } \\
\text { для Российской Федерации на } \\
01.01 .2019 \text { года } 75 \text { из } 100 \text { баллов }\end{array}$ \\
\hline Прочие виды рисков & $\begin{array}{l}\text { Данный вид риска характеризует уязви- } \\
\text { мость системы профессионального образо- } \\
\text { вания в прочих аспектах }\end{array}$ & - \\
\hline
\end{tabular}

* Информация здесь и ниже получена на основе опроса ряда специализированных экспертов в Российской Федерации в 2019 году. Баллы измеряются в целых положительных величинах от 0 до 100 единиц включительно. 
ского характера, уровень воздействия которых определен соответственно в 65 и 55 баллов из 100 возможных;

- менее активно на систему высшего профессионального образования в Российской Федерации в аспекте экономической безопасности, влияют информационные, юридические и политические риски.

Основные виды рисков, присущие системе высшего профессионального образования [6, 9] в Российской Федерации, приведенные в таблице 2 , в совокупности формируют часть проблемного поля, определяющего положение системы экономической безопасности страны в тот или иной период времени.

Многообразие рисков, указанных в таблице 2 , актуализирует в значительной мере вопрос об их анализе, который может быть осуществлен на основе следующих подходов (таблица 3).

На основе данных таблицы 3 можно сделать следующие выводы:

- наиболее актуальным подходом к анализу рисков системы высшего профессионального образования Российской Федерации является комплексный или матричный вариант с рейтингом 9 баллов из 10 возможных (практически максимальная оценка). К основным плюсам данного подхода можно отнести: высокую точность применения; возможность работы в рамках различных сценариев с заданными пользователем параметрами; практически, неограниченный методический ресурс, используемый в процессе анализа рисков; минимальными информационными требованиями, предъявляемыми к элементам анализа (непосредственно к описанию и значениям факторов, используемым в процессе анализа). Явными минусами указанного подхода являются: высокая сложность применения моделей анализа рисков (фактически, применение подхода лишь при условии использования автоматизированных программных продуктов с нейросетевым инструментарием); необходимость представления о результативности локальных методик, используемых в процессе проведения анализа; достаточная сложность интерпретации полученных результатов, ввиду наличия нескольких сценариев работы;

- чуть меньшую актуальность (рейтинг 7 баллов из 10 возможных) в процессе анализа рисков системы высшего профессионального образования имеет интегральный подход, связанный с последовательным применением нескольких методов для анализа конкретного вида риска. Значимыми плюсами данного подхода, на наш взгляд, являются: существенная объективность выводов, полученных в результате проведения инициатив; использование нескольких методов для анализа каждого вида риска. К минусам данного подхода, на наш взгляд, можно отнести: высокую сложность применения, в первую очередь, в части согласования выводов, полученных в рамках применения различных методов ана-

Таблица 3. Подходы к анализу рисков системы высшего профессионального образования Российской Федерации

\begin{tabular}{|c|c|c|}
\hline Наименование подхода & Характеристика подхода & $\begin{array}{c}\text { Актуальность } \\
\text { применения подхода * }\end{array}$ \\
\hline Дифференцированный & $\begin{array}{l}\text { Суть подхода заключается в разноплано- } \\
\text { вом (применяющим один метод для ана- } \\
\text { лиза каждого риска) анализе различного } \\
\text { вида рисков системы высшего професси- } \\
\text { онального образования }\end{array}$ & $\begin{array}{l}\text { Актуальность применения } \\
\text { подхода на рынке Российской } \\
\text { Федерации может быть оценена } \\
\text { в } 5 \text { баллов из } 10 \text { возможных }\end{array}$ \\
\hline Интегральный & $\begin{array}{l}\text { Суть подхода заключается в объединен- } \\
\text { ном (применяющи в определенной } \\
\text { последовательности несколько различ- } \\
\text { ных методов для анализа каждого риска) } \\
\text { анализе различного вида рисков системы } \\
\text { высшего профессионального образования }\end{array}$ & $\begin{array}{l}\text { Актуальность применения } \\
\text { подхода на рынке Российской } \\
\text { Федерации может быть оценена } \\
\text { в } 7 \text { баллов из } 10 \text { возможных }\end{array}$ \\
\hline Комплексный (матричный) & $\begin{array}{l}\text { Суть подхода заключается в комплексном } \\
\text { (применяющим параллельно несколько } \\
\text { различных методов для анализа всех } \\
\text { рисков) анализе различного вида рисков } \\
\text { системы высшего профессионального } \\
\text { образования }\end{array}$ & $\begin{array}{l}\text { Актуальность применения } \\
\text { подхода на рынке Российской } \\
\text { Федерации может быть оценена } \\
\text { в } 9 \text { баллов из } 10 \text { возможных }\end{array}$ \\
\hline
\end{tabular}

* Информация по актуальности применения подходов на рынке Российской Федерации на начало 2019 года была получена путем объединения результатов исследований ряда консалтинговых компаний $[7,8,9,10]$. 
лиза рисков; высокие требования к первичным данным, используемым для анализа рисков; необходимость привлечения экспертной команды разноплановых аналитиков;

- наименьшая для Российской Федерации актуальность (рейтинг 5 баллов из 10 возможных) имеет место для подхода, основанного на дифференциальном применении методов анализа рисков системы высшего профессионального образования. Значимыми плюсами здесь, по нашему мнению, являются: относительно небольшие затраты времени, необходимые для проведения анализа; возможность проведения всех видов работ узкой экспертной группой; легкость интерпретации полученных результатов. Ключевыми минусами анализируемого подхода, на наш взгляд, являются: относительно низкая объективность полученных результатов; высокие риски выбора неэффективного метода для проведения анализа; невозможность использования в работе сценарного подхода.
Таким образом, можно сделать вывод, что состояние экономической безопасности Российской Федерации зависит от множества элементов, одним из которых является система высшего профессионального образования.

Анализ рисков системы высшего профессионального образования Российской Федерации может быть проведен в рамках следующих элементов: политические риски, экономические риски, информационные риски, юридические риски, технологические риски, социальные и прочие виды рисков.

Подходы к анализу рисков системы высшего профессионального образования включают: дифференцированный, матричный (комплексный) и интегральный. Проведенные авторами исследования позволили прийти к выводу, что наибольшую актуальность для Российской Федерации среди всех подходов имеет комплексный вариант.

\section{Библиографический список}

1. Николаева Е.А., Григорьева И.В. и др. К аспектам влияния оценки эффективности деятельности профессорско-преподавательского состава высшего учебного заведения на укрепление экономической безопасности Российской Федерации / Е.А. Николаева, И.В. Григорьева, И.С. Казимирова, Е.И. Соколова // Экономические науки - Москва: Изд-во ООО «24-Принт», 2019. - № 3.- С. 62-67.

2. Селезнева А.В., Лепешкина А.В. Вопросы управления рисками в системе профессионального образования / A.В. Селезнева, А.В. Лепешкина // MASTER`S JOURNAL - Саратов: Изд-во «Пермский национальный исследовательский политехнический университет», 2018.- № 2.-C. 15-22.

3. Сидорова E.E., Циликова М.С. и др. Экономические аспекты корпоративной интеграции подразделений высшего учебного заведения в целях повышения качества образовательного процесса / М.С. Циликова, Е.Е. Сидорова, И.В. Аввакумова, Д.А. Прусакова // Экономические науки - Москва: Изд-во ООО «24-Принт», 2018. - № 10.- С. 75-79.

4. Соколова Е.И. К вопросу обеспеченности сферы высшего профессионального образования в российской федерации стратегиями развития экономической безопасности / Е.И. Соколова // Экономические науки Москва: Изд-во ООО «24-Принт», 2019.- № 6.- С. 87-91.

5. Alfers, L.; Lund, F.; Moussié, R. 2017. «Approaches to social protection for informal workers: Aligning productivist and human rights-based approaches», in International Social Security Review, Vol. 70, pp. 67-85.

6. Wilkoszewski, H. and E. Sundby (2016), «From Hard to Soft Governance in Multi-level Education Systems», European Journal of Education, Vol. 1, No. 4, pp. 447-461.

7. Компания «Ernst\&Young» [Электронный ресурс]: аналитические материалы - Официальный сайт рейтингового агентства «Ernst\&Young», 2019.- Режим доступа: https://www.ey.com/ru

8. Компания «КPMG» [Электронный ресурс]: аналитические материалы - Официальный сайт компании «KPMG», 2019.- Режим доступа: https://home.kpmg/ru/ru/

9. Компания «PricewaterhouseCoopers» [Электронный ресурс]: аналитические материалы - Официальный сайт компании «PricewaterhouseCoopers», 2019.- Режим доступа: https://www.pwc.ru

10. Рейтинговое агентство «Эксперт РА» [Электронный ресурс]: аналитические материалы - Официальный сайт рейтингового агентства «Эксперт РА», 2019.- Режим доступа: https://raexpert.ru 